\title{
'The Power of Two Homelands': Musical continuity and change, the evocation of longing and an Altai Urianghai song ${ }^{1}$
}

\author{
Rebekah Plueckhahn
}

\section{Introduction}

The singing of songs amongst the Altai Urianghai in Duut district, Hovd Province, Mongolia, forms a powerful, emotionally evocative and performative act. As noted elsewhere in Mongolia, it is often in song texts that bittersweet emotions of loss or longing are expressed ${ }^{2}$ - emotions that are not normally displayed in other forms of sociality. In this paper, I discuss the particular poetic encapsulation of longing and loss contained in a well-known song amongst the Altai Urianghai people in Hovd Province, Mongolia. The performance of this particular song of longing and loss is a multivalent phenomenon that occurs in a context of cultural redefinition and rediscovery. In post-socialist Mongolia, song forms and performers themselves have been shaped by the experiences of past socialist cultural policies and post-socialist relaxations in public cultural practice. A close look at this particular song reveals this multi-layered history of social and political change. Evocative song lyrics can express emotional states of being whilst simultaneously articulating 'ethnic' delineation, cultural change and perceptions of cultural continuity. The Altai Urianghai short 'folk' song (bogino ardyn duu) ${ }^{3}$ entitled 'Hoyer Nutgiin Erh', or 'The Power of Two Homelands', is one such song. Popular amongst Altai Urianghai people in both

\footnotetext{
1 I would like to thank S. Undargaa for assistance with additional translation of the song lyrics and J. Bolorchimeg for translation of interviews with M. Ganbold and N. Sengedorj. I also wish to thank two anonymous reviewers for their valuable suggestions and ethnomusicologist Andrew Colwell from Wesleyan University for reading a draft of this paper and providing invaluable insights and suggestions. I also wish to thank Professor Stephen Wild and Dr Di Roy for their careful editing and my supervisor, Professor Howard Morphy, for suggestions on a draft of this paper. Last, I would like to thank M. Ganbold of Hovd University and the many Duut friends who shared their enthusiasm for music with me throughout my months of fieldwork.

2 Højer, L. 2004, Dangerous communications: enmity, suspense and integration in post socialist northern Mongolia, PhD thesis, Department of Social Anthropology, University of Cambridge, Cambridge, p. 117.

3 In this paper, I use a system of Mongolian transliteration as used by Empson (Empson, R. 2011, Harnessing Fortune: Personhood, memory and place in Mongolia, Oxford University Press, Oxford and New York) when she follows Lessing, F. et al. 1960, Mongolian-English Dictionary, Mongolian Society, Indiana University Press, Bloomington.
} 
Hovd and Bayan Olgii provinces, it simultaneously reveals the use of textual poetic devices that evoke a strong sense of longing and loss over a geographical distance. At the same time, it embodies a delineation of Altai Urianghai identity in post-socialist Mongolia on melodic and performative levels.

This paper draws from 14 months of doctoral fieldwork in Mongolia spanning 2009, 2010 and 2012. During this time, I largely conducted research in the rural district of Duut Sum, Hovd Province, Mongolia. Duut Sum is home to $1287^{4}$ Altai Urianghai ${ }^{5}$ people, an ethnic group within Mongolia. ${ }^{6}$ It is an area of carefully demarcated herding rangeland, with a central village, or sum centre (sumyn töv), located roughly in the north-east of the district. During my fieldwork, I lived primarily in the district centre where I assisted my host family with daily activities, visited musicians, took music lessons and attended concerts. By living in the district for an extended period, I was able to participate in a wide range of activities and ceremonies through which I was able to learn about the differing forms of musical engagement undertaken by a wide sector of the population. I also travelled with my friends to the provincial capital of Hovd City, to other areas in western Mongolia and to Ulaanbaatar, following people in this mobile environment.

My doctoral research explores the significance of musical engagement in the ongoing post-socialist context amongst this group of Altai Urianghai. Since the fall of communism in 1990, Mongolia has been a fertile scene for an ongoing rediscovery and rearticulation of Mongolian cultural and spiritual practices, and historical origin. ${ }^{7}$ Certain Altai Urianghai musical genres are now being included in this cultural veneration as genres that link Mongolia to an ancient past. ${ }^{8}$ In my doctoral research, I focus on how Altai Urianghai people in and from

4 'Population and dwelling, 2010 National Census-Results-Sum/District [Hün Am, Oron Suutsnii 2010 oni Ulsyn Toollogo - ür dün-Sum/Dü̈reg]', viewed 29 July 2012, <http://www.toollogo2010.mn/yazi. php?category $=$ Result $>$

5 The total number of Altai Urianghai people in Mongolia is 26 684, with most located in western Mongolia (ibid.).

6 In describing the Altai Urianghai as an ethnic group within Mongolia, I am following the translation of the Mongolian term yastan, which literally translates to 'nationality' but is now used to denote a sub-ethnic group within Mongolia. Culturally, however, Altai Urianghai are considered Mongolian. Delineations of Altai Urianghai ethnicity largely occur through a spoken Urianghai language, which is a dialect of Mongolian, some different food preparation practices and, significantly, through the practice of specific musical genres. Given the changing significance placed on the term yastan, I understand that translating it to 'ethnicity' might be viewed as problematic; however, given that the Altai Urianghai differentiate themselves from other Mongolians, I have chosen to use the term 'ethnicity' as it best encapsulates this differentiation. For further definitions of the word yastan, and its increased usage in describing ethnic delineation during the socialist and post-socialist periods in Mongolia, see Bulag, U. E. 1998, Nationalism and Hybridity in Mongolia, Clarendon Press, Oxford.

7 Humphrey, C. 1992, 'The moral authority of the past in post-socialist Mongolia', Religion, State and Society, vol. 20, nos 3-4, pp. 375-89; Kaplonski, C. 2004, Truth, History and Politics in Mongolia, Routledge Curzon, London and New York.

8 O. Undarmaa 2010, ‘E. Baatarjav, Tsoor bol hün törölhtnii uugan högjim [E. Baatarjav: the Tsuur, people's native original music]', Önöödör, 12 November, pp. E1-E2. 
Duut Sum negotiate this musical notoriety in different ways, and I draw from an in-depth ethnographic focus on how musical engagement forms a fundamental part of ongoing sociality between people within Duut Sum. In doing so, I aim to build upon contributions previously made to the scholarship of music in Mongolia. The nature of the particular place-based ethnographic focus of my doctoral research builds upon the work of Pegg, ${ }^{9}$ whose encompassing study presented a detailed depiction of Mongolian music from across Mongolia at the end of communism. My work also builds upon the work of Marsh, ${ }^{10}$ who focused upon the correlations and continuity between socialist and post-socialist musical experiences in Mongolia through the prism of a detailed study of the morin huur or horse-head fiddle. Given attention paid to Altai Urianghai musical practice in post-socialist Mongolia, in my doctoral work I aim to reveal how musical practice is an extremely dynamic medium through which Duut Altai Urianghai situate themselves socially, geographically and spiritually in the post-socialist context. The song 'The Power of Two Homelands' provides a key example of such Duut Altai Urianghai musical 'positioning'. It is the multi-layered nature of this song, the simultaneous reference to a cultural delineation and personal loss, that led me to choose it for this discussion surrounding laments and the role of song in loss and longing.

The discussion of lament or loss in song form in the Mongolian context presents some interesting questions. Whilst there are Mongolian musical genres of long song (urtyn duu) and short song (bogino duu) or short folk songs (bogino ardyn duu) that are recognised Mongolia wide, ${ }^{11}$ there is no specific genre of musical laments in wider Mongolian musical culture. Instead, songs of loss and longing tend to develop in particular historical and localised contexts. One such example was during the political purges of the 1930s in which many Buriad Mongolians from north-central Mongolia were persecuted. Empson discusses how during this time of 'great uncertainty people created a special genre of songs called "persecution songs" (helmegdliin duu) to lament the loss and absence of their husbands, brothers, grandfathers, and sons'. ${ }^{12}$

Instead of possessing a specific genre of laments, the present-day Altai Urianghai in Duut more commonly sing in order to make things good, to sway a given social event into a positive direction. The singing of long song, short or folk songs occurs in concerts, informal social gatherings or life-cycle celebrations (nair) such as weddings and children's hair-cutting ceremonies. During these occasions, songs are sung with the aim of creating celebration, or bayar tsengel-

9 Pegg, C. 2001, Mongolian Music, Dance and Oral Narrative, University of Washington Press, Seattle.

10 Marsh, P. 2002, Moving the world through two strings: the horse-head fiddle and the cosmopolitan reimagination of tradition in Mongolia, $\mathrm{PhD}$ thesis, Department of Central Eurasian Studies, Indiana University, Bloomington.

11 Pegg, Mongolian Music, Dance and Oral Narrative.

12 Empson, Harnessing Fortune, pp. 43-4. 
making things good - to ensure a good future and fortune (hishig buyan) for the new bride and groom or a good life for the child whose hair is being cut for the first time, approximately at the age of three. This causal relationship between perceptions of time and future and the singing of songs can result in great social emphasis being placed on the importance of 'good' singing and musical performance, rather than performances that evoke sadness or despair. During such ceremonial occasions, the singing of sad songs (gunigiin duu) in a sorrowful way is not allowed. If someone begins to sing a sad song in a sad way, they are quickly hushed by surrounding family members.

\section{'The Power of Two Homelands': Poetic analysis and interpretation}

Despite this emphasis on song performance creating a positive sense of being, song texts often contain an evocation of a particular emotional bittersweetness. Analysis of the text of the song 'The Power of Two Homelands' reveals an emotional lament over a particularly Altai Urianghai conundrum. In Duut's mountainous environment, herders move between summer, autumn/winter and spring encampments or sometimes more frequently according to pasture availability and suitability. In winter, the mountain passes in the southern Duut subdistrict of Höh Belchir Baga (Blue Confluence of Rivers Subdistrict) are often covered in snow, making them difficult to traverse. Many herders from this subdistrict move to the centre of Höh Belchir Baga (Höh Belchir Bagiin töv) as their winter encampment. The long valley floor provides protection and means that Höh Belchir Baga herders are able to travel to the district centre during winter; however, due to the high snowfall, movements between encampments outside the subdistrict centre are considerably difficult. The type of movement required for herding animals is described as nü̈h - to move or shift pastures. The song 'The Power of Two Homelands' describes the emotional experience contained within and as part of this kind of movement: mobile pastoralism or nüüh between high mountain passes.

This song describes two lovers, both from different herding families, who met during summer months when their respective encampments were placed nearby high in the mountains. During summer, animals prefer to graze in the cooler reaches of mountainsides to escape the gnats and mosquitoes that breed in lower-lying waterways. Autumn has arrived, and the lovers have separated, each having 'nomadised' (nüüh) with their respective families to their autumn and winter encampments. This song evokes their longing for each other whilst they 
are separated by frozen, snowed-in winter mountain passes that are impossible to traverse between the cold months of November and March. As noted by Urianghai scholar M. Ganbold, from Duut Sum and now living in Hovd:

This is a song which shows the life of Urianghai people. During summer time they will go over the Altai Mountains...Young people will meet and become friends. In autumn they will return to their autumn camps on two opposite sides [of the mountains]. Then snow will fall and the road will be blocked... They are saying that we split not because we wanted to, we split because we had different homelands, we had to move different ways with our livestock. ${ }^{13}$

In the song text itself are grammatical, poetic devices that encapsulate a simultaneous sense of hope and longing along with a sense of futility and sadness. The artful juxtaposition of these feelings of push and pull between personal desire and familial obligation forms the core of the song text. The lovers are searching for possible ways to meet, but, at the same time, know with each mention of a possible avenue that it will be impossible to do so:

\section{'Hoyer Nutgiin Erh'}

Uulaar yaj dawaa maanim

Uulzaad yaj salnaa maanim

Hadaar yaj dawna maanim

Hargaldaad yaj salnaa maanim

Sal'ya geed salsangui maanim

Salangid nutgiin erheer sallaa

Hold'yo geed holdsongui maanim

Hoyer nutgiin erheer holdloo

Hetseer yaj dawna maanim

\section{'The Power of Two Homelands'}

My dear, by means of the mountain how will we cross the mountain pass?

My dear, we metand then how did we become separate?

My dear, by means of the cliff how will we cross over?

We came into conflict [with terrain] and then, how did we become separate?

Not from a call for seperating from each other

This seperation comes from a power of separate homelands, to each of us, Not from a call for staying away from each other

Staying away comes from a power of two homelands

My dear, how will we cross over the the mountain ridge?

13 M. Ganbold, Interview with the author, 29 October 2010. 
Het $n^{\prime}$ yaj uulzana maanim

Dawaagaar yaj dawna maanim

Daraa n' yaj salna maanim

Sal'ya geed salsangui maanim

Salangid nutgiin erheer sallaa

Hold'yo geed holdsongui maanim

Hoyer nutgiin erheer holdloo
My dear, how soon can we meet?

My dear, by means of the mountain pass, how will we cross over?

And how could we separate, when meeting, each other?

Not from a call for seperating from each other

This seperation comes from a power of separate homelands, to each of us, Not from a call for staying away from each other

Staying away comes from a power of two homelands*

\footnotetext{
* Original transcription in Cyrillic by M. Ganbold (1991, Urianghai Ardyn Duunuud [Urianghai Folk Songs], Edited by D. Tsedendulam, Publisher unknown, Hovd City, Mongolia). Transliteration and initial translation by R. Plueckhahn, 2011. Additional translation by S. Undargaa, 2011. In the English translation of this song text, I aimed to provide a literal translation in order to reveal the juxtaposition between the terrain and people's desired actions, which is encapsulated in the original Mongolian.
}

This song text evokes a deep emotional state of bittersweet gain and subsequent loss as a result of their separation. The loss is recognised as inevitable - the two lovers must go with their respective families - but that inevitability only compounds its bittersweet sentiment.

This emotional bittersweetness is created poetically through the use of particular grammatical devices:

\section{Verse 1}

Uulaar yaj dawaa maanim

Uulzaad yaj salnaa maanim

Hadaar yaj dawna maanim

Hargaldaad yaj salnaa maanim
My dear, by means of the mountain how will we cross the mountain pass?

My dear, we met and then, how did we become separate?

My dear, by means of the cliff how will we cross over?

We came into conflict [with terrain] and then, how did we become separate?

The poetic 'pull and push' is between the lovers' feelings for each other and their subsequent separation. In each line, the word yaj or 'how' forms the central word of the sentence. It is the point of articulation between two opposing 
phenomena: the 'separating' environment and the connection between the two lovers. The word yaj is preceded by the alternating use of two different suffixes. The first (as seen in line one) is the instrumental suffix, 'by means of', or '-aar'. Here the instrumental suffix is used to describe the traversing of a possible pathway. As seen in line three, the singer is asking whether they can travel to each other via the cliff- a potential route to travel on, but in this case it is covered in snow and they cannot cross. The second suffix used is the verb suffix '-aad', which translates to 'and then'. It can be used to describe an action that has occurred sometime before another potential action takes place. ${ }^{14}$ As seen in line two, the lovers are lamenting as to how, after meeting and spending time together, they separated, evoking a sense of incredulity over this situation. The usage of these two alternating suffixes with the word 'how' both encapsulates and creates a bittersweet lament over the lovers' predicament.

These intense romantic, bittersweet feelings have occurred as a consequence of the nature of the landscape in which these two people herd with their families. In the song text, the nature of this landscape is described as a form of power or 'erh' of their two homelands or 'nutag':

\section{Verse 4, lines 3 and 4}

\section{Hold'yo geed holdsongui maanim}

Hoyer nutgiin erheer holdloo
Not from a call for staying away from each other

Staying away comes from a power of two homelands

These two words - power (erh) and homeland (nutag) - are important, polysemic terms. A person's homeland or nutag is a nuanced term and its 'meaning depends on the situation'. ${ }^{15}$ For instance, if someone from Duut is in Ulaanbaatar, their homeland could be described as Hovd, or western Mongolia, as well as Duut itself. This 'term with variable geometry...connects dispersed places', ${ }^{16}$ and is a place of great attachment and one that conjures up a great deal of nostalgia if a person is away from it. It includes 'the network of social relationships' ${ }^{17}$ and can often include one's birthplace or an area where one's parents reside or used to reside. In the case of this song, homeland refers to the routes travelled by familial encampments as they move between seasonal pastures. The two lovers have strong, interconnected age and gender-specific obligations and emotional attachment to their respective family's herding activities and movements. The movement with family among this landscape ensures the family's ongoing growth

14 Uranchimeg, T., Elliot, D. and Yendii, P. 2009, An Elementary Mongolian Grammar, Publisher unknown, Ulaanbaatar, p. 75.

15 Legrain, L. 2009, 'Confrontation on the River Ivd, or, how does music act in social life?', Inner Asia, vol.

11 , no. 2 , pp. $335-58$, p. 338 .

16 Ibid., p. 338.

17 Ibid., p. 339. 
and nurturance, but comes at a cost of separation - separation from other linked familial networks herding or living elsewhere and, in this case, separation of an emotional connection 'outside' their respective family's herding movements.

The power, erh, of their homelands is thus twofold. It is the power to provide sustenance to their families, 'a means by which people actively generate their livelihoods and relate with each other ${ }^{\prime}{ }^{18}$ however, because of the movement required in order to ensure this growth, it is the power that simultaneously separates and keeps them apart. Erh has the added dimension that it can refer to the inherent spiritual power of the landscape itself. As noted by Humphrey, in the Mongolian context, 'it is not contemplation of the land (gazar) that is important but interaction with it, as something with energies far greater than the human'. ${ }^{19}$ Whilst Humphrey is correct in stating that interaction with the landscape is paramount in Mongolian transhumance, this interaction often provokes a form of contemplation, as seen in 'The Power of Two Homelands'. This song is a contemplation of the nature of both inhabiting and interacting with this landscape. The separation of the two lovers is viewed at once as necessary and also 'experienced as forced upon them' ${ }^{20}$ Such is the power of the landscape to determine people's movements where instead of transforming the landscape Mongolians 'move within a space and environment where some kind of pastoral life is possible and "in-habit" it'. ${ }^{21}$ In her work, Empson ${ }^{22}$ describes how people extract 'parts of people, animals and things when they leave or separate, and then containing these parts inside the ger' ${ }^{23}$ in order to harness fortune. I propose that whilst not directly related to the containment of fortune, this song text is a way to maintain attachment in the face of movement, to 'contain' something of their relationship in the face of separation.

\footnotetext{
18 Empson, Harnessing Fortune, p. 319.

19 Humphrey, 'The moral authority of the past in post-socialist Mongolia', p. 135.

20 Empson, Harnessing Fortune, p. 13. See Empson, R. 2007, 'Separating and containing people and things in Mongolia', in Amiria Henare, Martin Holbraad and Sari Wastell (eds), Thinking Through Things, Theorising Artefacts Ethnographically, Routledge, London and New York, pp. 113-40; and Harnessing Fortune (specifically pp. 13-15 and Chapters 2, 3 and 9) for a more in-depth discussion on 'containment and separation' in the creation of growth in both people and fortune in the creation of Mongolian personhood.

21 Humphrey, C. 1995, 'Chiefly and shamanist landscapes in Mongolia', in E. Hirsch and Michael O'Hanlon (eds), The Anthropology of Landscape: Perspectives on place and space, Clarendon Press and Oxford University Press, Oxford and New York, pp. 135-62, at p. 135.

22 Empson, 'Separating and containing people and things in Mongolia', pp. 113-40; Empson, Harnessing Fortune.

23 Empson, Harnessing Fortune, pp. 13-14.
} 


\section{Socialist Cultural Programs and the Movement of 'The Power of Two Homelands'}

Stepping back from the song text, the song itself represents a form of mobility and traversing of landscape and social space. It is indicative of a wider form of nostalgia that extends beyond the bittersweet emotion contained in its text, and this part of the song's significance can be seen when focusing on the role of the song's melody. During my fieldwork, 'The Power of Two Homelands' was a song that was considered unequivocally Altai Urianghai, unlike other songs sung in Duut of which the origins were debated. Yet, despite its locality, it also correlates with a national song genre. Once, when I was in Ulaanbaatar staying with a Zahchin friend originally from Hovd, I worked on a musical transcription of the song. My friend commented on what I was doing and I played her a recording of it. She described the song as a Mongolyn ardyn duu: a Mongolian song known throughout the country, and one that was first popularised under socialism.

This dual association as a song that is both Altai Urianghai and national stems from practices undertaken during Mongolian socialist cultural programs. These programs were part of an overall attempt to create a 'new national identity for a unified socialist nation' or ündesten. ${ }^{24}$ Following increased hardline socialist directives during the 1930s in the Soviet Union, in Mongolia, 'cultural enlightenment' programs were intensified. ${ }^{25}$ Part of this cultural program was to ensure the 'synthesis of diverse performance styles into one intellectual cultural and national style' with the 'expectation that each yastan (nationality) would renounce its own identity to become part of a unified socialist ündesten' ${ }^{26}$ In the creation of this unified nationalism, an emphasis was placed on the eastern, halh Mongol ethnic majority. During the 1950s, government-led ethnographers collected 'songs, music, myths, legends and epics' ${ }^{27}$ Composite versions of songs that were 'national in content' were published. ${ }^{28}$ This resulted in many songs from different areas and yastans or ethnic groups being published in national compendiums as halh, which, by association, were deemed national Mongolian songs by a halh political elite. As noted by M. Ganbold: 'during socialist times, songs weren't labelled Urianghai or Zahchin, only as eastern Mongolian folksong. There were many [western, Altai] Urianghai songs included in this [so-called] "eastern" collection. ${ }^{29}$

\footnotetext{
24 Pegg, Mongolian Music, Dance and Oral Narrative, p. 249.

25 Ibid., p. 254.

26 Ibid., p. 249.

27 Ibid., p. 249.

28 Ibid., p. 249.

29 M. Ganbold, Personal communication, 29 October 2010.
} 
These collection projects coincided with socialist changes in performance practice. The changes were aimed to 'raise the cultural level'30 of rural Mongolian people, and included the opportunity for such people to be involved in the stage musical arts. This happened through the establishment of, first, amateur and subsequently professional musical ensembles, theatres, concert halls and cultural clubs throughout the country ${ }^{31}$ as early as the mid 1920 s. $^{32}$ These performance practices increased the movement of singers and brought together different ethnic musical influences into the same concert programs. Musicians from different rural areas brought songs they had previously learnt in ceremonial spaces into the concert space. In Hovd, the provincial centre, Hovd City's Drama Theatre was an important locus of cultural performance in the region, and to some extent remains so today. Many well-known performers in surrounding sums were requested to come and sing in the Hovd Theatre, some gaining ongoing notoriety for their musical prowess.

'The Power of Two Homelands' was swept up into these socialist performance practices of collecting, reframing and disseminating music. As also noted by M. Ganbold, how this exactly occurred is likely to have been a result of these socialist cultural programs. A singer brought this song to the stage and it was subsequently popularised and disseminated throughout the country, either in compendiums or via radio. M. Ganbold states: 'All Mongolian people know about this song. During the socialist period, a famous singer sung that song. They sung that song under an eastern Mongolian song name, but it is an Urianghai song. Urianghai is the birthplace of this song. ${ }^{33}$

\section{Music, Emotion and Cultural Memory in Song}

In contemporary Mongolia, songs are performed both for ceremonial occasions and on stage, where the stage has become an integral part of local musical practice. Songs that previously were included in these socialist collections now form a significant part of the mosaic of current Duut musical repertoire. Since 1990, 'The Power of Two Homelands' has become a popular song amongst Altai Urianghai people in western Mongolia, and it is well known more widely by people in Hovd. It is now described as an authentic Altai Urianghai song, forming another part of the song's 'journey' from one that was purely Altai Urianghai to a national Mongolian song, and its subsequent reclamation as significant in contemporary Urianghai cultural practice.

30 Marsh, Moving the world through two strings, p. 65.

31 Ibid., p. 65.

32 Pegg, Mongolian Music, Dance and Oral Narrative, p. 253.

33 M. Ganbold, Interview with the author, 29 October 2010. 

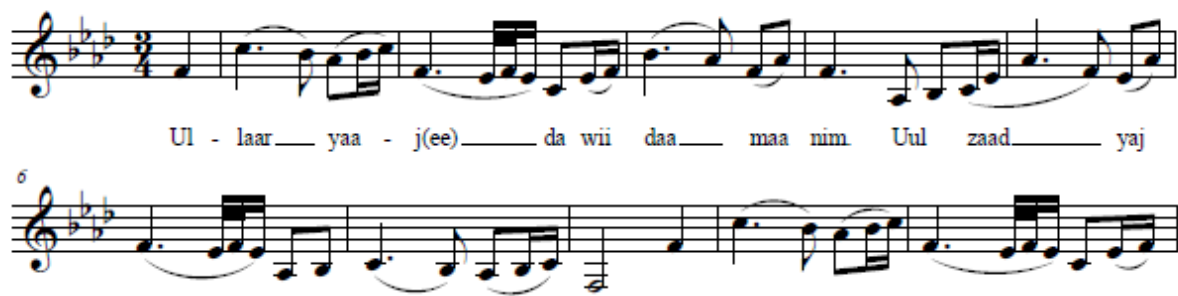

(ee) sal ii

daa__ maa__ nim. Had - aar

ya - j(ee) daa - win
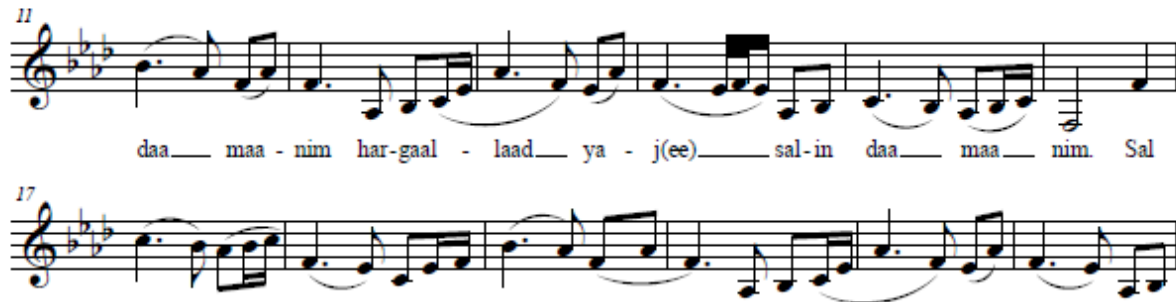

sa-la-ha $-500-$

sal-lin gui nut gin__ er -
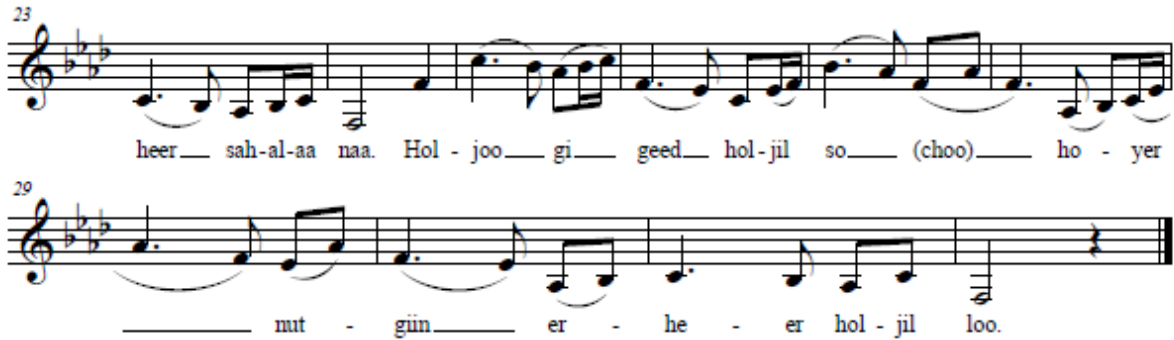

Figure 1 'The Power of Two Homelands'. Tsevegjav singing in his ger, 01.12 .2010

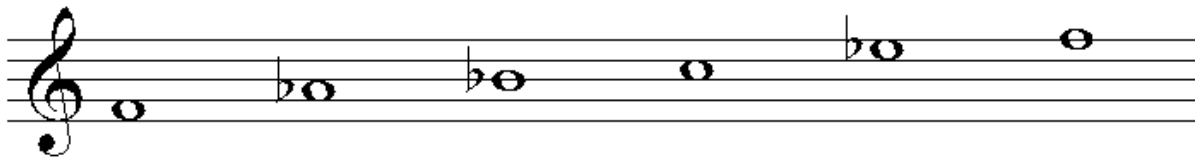

Figure 2 Pentatonic minor scale used in 'The Power of Two Homelands' 
'The Power of Two Homelands' was sung often throughout my fieldwork: on long car trips on the way to Hovd and for ceremonial occasions - both weddings and hair-cutting ceremonies. When someone started singing this song, the opening notes of the melody evoked nods of agreement, where people indicated that this song is Altai Urianghai. Notably, among the different examples of the song sung both to me and in concerts, the melody was the most consistent musical element of each rendition. Whilst Legrain notes in his work on Darhad music in northcentral Mongolia that 'people say that lyrics of songs travel from one melody to another depending on the origin of the singer', ${ }^{34}$ in the case of 'The Power of Two Homelands', the melody stayed consistent whilst singers added their variation to the lyrics. Whilst the overall topic and content of the song remained consistent between singers, singers added their own poetic or grammatical variations, as seen in this rendition sung by Duut singer Tsevegjav (see audio example $1^{35}$ ). In this version, Tsevegjav sings the same lyrics as transcribed by M. Ganbold in 1991; however, Tsevegjav adds his own grammatical changes, including several vocables (written in parentheses).

Significantly, the song was also a popular choice at the Altai Urianghai Ih Naadam or 'Big Festival' held in Altaintsogts Sum in Bayan Olgii Province in September 2009. The singer Tsendmaa from Mönhairhan Sum, a neighbouring Altai Urianghai sum to Duut, performed the song with two different types of accompaniment, both of which could be said to reflect the song's varied musical background. First, in this version, a heterophonic accompaniment was played by Purevdorj, a morin huur (horse-head fiddle) player who was living in Duut in 2009 and 2010. Halfway through the song, a chordal synthesiser took over the accompaniment, played by a man from the wider Altai Urianghai area.

See audio Example 2 'The Power of Two Homelands', performed by Tsendmaa, Purevdorj on morin huur and a synthesiser player at the Altai Urianghai Ih Naadam, Altaintsogts Sum, Bayan Olgii Province, 11 September 2009. ${ }^{36}$

While this melody is recognised as Altai Urianghai, it is also acknowledged as having an innate authenticity by other peoples of different ethnicities within Hovd. As noted by a well-known western-halh musician in Hovd, Sengedorj, the power of the melody is a marker of its authenticity. He locates the melody's authenticity in its ability to evoke emotions stemming from the mountainous landscape. Sengedorj remarked:

\footnotetext{
34 Legrain, 'Confrontation on the River Ivd', p. 338.

35 View associated media files via the ANU E Press website <http://epress.anu.edu.au/titles/humanitiesresearch-journal-series/volume-xix-no-3-2013>

36 View associated media files via the ANU E Press website <http://epress.anu.edu.au/titles/humanitiesresearch-journal-series/volume-xix-no-3-2013>
} 
[N]ature or mountains never look bad in any kind of society or time. That mountain was beautiful in socialist time, it is also beautiful in capitalist time... This song The Power of Two Homelands, is in a kind of classic form. It requires a lot of voice range, and from that voice range you can see the inner feeling of the person singing that song. This song was born by the force of circumstances [these lovers] found themselves in. ${ }^{37}$

For Sengedorj, the pentatonic minor scale and the wide vocal range required to sing this song constitute a musical encapsulation of the power of the emotion the song expresses. The combined parts of the song - the melody, the words and the mountainous Altai Urianghai environment from which it originatedare what for Sengedorj imbue this song with a sense of authenticity, of having stemmed from humans' relationships with and connection to the elements of nature in this region.

The current performance practice of and discourse surrounding 'The Power of Two Homelands' present a complex interweaving of different perspectives around the theme of loss amongst a group of people who have experienced vast political and social changes, and for whom movement and separation are continued parts of everyday life. The singing of this song effectively evokes the power of emotional sadness brought about by a separation between differing homelands and the realities that this mountainous mobile pastoralist existence presents. At the same time, this song-having stemmed from the mountains, from a regional Altai Urianghai nutag or homeland - results in the song forming an important part of the musical re-imagination of an Altai Urianghai space in the face of past socialist cultural practices and ongoing social change. In the reflections of the musician Sengedorj, this song also represents the power of emotion as a driving force in the creation of song. It was people's connection to the mountains themselves that drove them to experience and lament the loss of each other, where this song is 'the narrative of peoples' heart[s]'.$^{38}$

37 N. Sengedorj, Interview with the author, 30 October 2010.

38 Ibid. 